Crop Breeding and Applied Biotechnology 14: 29-35 2014

Brazilian Society of Plant Breeding. Printed in Brazil

\title{
ARTICLE
}

\section{Variability, heritability, and correlations of agronomic traits in an onion landrace and derived $S_{1}$ lines}

\author{
Bettina Porta ${ }^{1 *}$, Mercedes Rivas ${ }^{1}$, Lucía Gutiérrez² and Guillermo A Galván ${ }^{3}$
}

Received 09 July 2012

Accepted 08 January 2014

\begin{abstract}
This study assessed variability, heritability and correlations of agronomic traits in an onion (Allium cepa L.) landrace and derived $S_{1}$ lines after a single selfing generation. Bulbs used to develop $S_{l}$ lines were selected for shape, colour and high number of skins. Fifty-one $S_{1}$ lines and the original population were evaluated using an incomplete random block design. The original population and $S_{1}$ lines were highly diverse for quantitative and qualitative traits. $S_{1}$ lines were significantly different, with transgressive segregation for number and maximum leaf length, bulbing index, bulb weight, diameter, and dry matter content. Variances within $S_{1}$ lines were greater than among $S_{1}$ lines for all traits. Bulb colour and number of skins responded to selection. Heritabilities for dry matter and soluble solids were $52.6 \%$ and $36.1 \%$ respectively. Both traits were highly correlated. The development of $S_{1}$ lines allowed the expression of genetic variation and the identification of better genotypes for agronomic traits of interest.
\end{abstract}

Keywords: Selfing, transgressive segregation, inbreeding depression, dry matter, soluble solids.

\section{INTRODUCTION}

Onion (Allium cepa L.) was originated in Central Asia and it has been cultivated since ancient times $(3000 \mathrm{BC})$ because of its unique flavour and medicinal properties (Galmarini et al. 2001, Shigyo and Kik 2008). Onion is the second most valuable vegetable crop worldwide, after tomato (FAOSTAT 2011, http://faostat.fao.org). In Uruguay (30-35 $\mathrm{SL})$, onion is one of the main vegetables in regard to number of farmers and acreage (DIEA 2010). The crop is based on locally improved cultivars and landraces maintained by small producers (Galván et al. 2005). Landraces originated from varieties brought by several waves of European Mediterranean immigrants. Natural and farmer-driven selection could have played in adaptation to new environmental conditions, leading to the development of populations with specific attributes (Hardon and De Boef 1993). However, most landraces do not have the characteristics that determine the good quality and uniformity required by the market (González et al. 2000). Nevertheless, landraces are well adapted to local edaphic and climatic conditions, resulting in high yields and better post-harvest storage ability in comparison with introduced cultivars. Landraces also have high genetic diversity and, consequently, are interesting as raw material to be used in plant breeding programmes (Galván et al. 2005).

Onion landraces with high genetic diversity have potential in selection for development of cultivars with favourable agronomic and market traits, such as high number of skins and dark brown colours of skins, round shaped bulbs, and high soluble solids and dry matter content. In Uruguay, the most common methods for onion breeding have been mass selection and selfing $\mathrm{S}_{1}$ lines (Vilaró et al. 2005). Mass selection has been useful for breeding from broadly diverse plant material. Selfing or full-sib family selection increases the expression of genetic variance on total variance, and allows refinement of the plant population with suitable traits (Poehlman and Sleper 1995). If variability within and among $\mathrm{S}_{1}$ lines is significant, the breeder may select both within and between lines. Subsequently, greater genetic progress is achieved in comparison with mass selection. Selfing is a more expensive method and thus would only be applied when mass selection yields scant genetic progress and when there is also enough genetic variability among $\mathrm{S}_{1}$ lines. The development of $\mathrm{S}_{1}$ lines may broaden genetic variability for specific traits as a result of transgressive segregation, manifestation of recessive genes, and fixation of alleles (Fehr 1987).

\footnotetext{
${ }^{1}$ Universidad de la República, Facultad de Agronomía, Departamento de Biología Vegetal, Avenida Garzón, 780, Montevideo, Uruguay. *E-mail: bporta@fagro.edu.uy

${ }^{2}$ Universidad de la República, Facultad de Agronomía, Departamento de Biometría, Estadística y Computación.

${ }^{3}$ Universidad de la República, Facultad de Agronomía, Departamento de Producción Vegetal, Centro Regional Sur, Camino Follé, km 36, Canelones, Uruguay
} 
Knowledge of the heritability of a trait assists in development of efficient breeding strategies (Poehlman and Sleper 1995). A high heritability index enables selection of a method for enhancing genetic progress. For Uruguayan onion landraces, there is no study on the heritability of agronomic traits such as soluble solids, dry matter, and bulb weight and diameter. Soluble solids and dry matter contents are traits that are positively correlated with the storage ability of onion bulbs (Patil and Kale 1985). Correlations among traits indicate associated responses that may occur when single trait selection is practised. Indirect selection based on correlated traits is often an effective manner of saving work and time in a breeding program. Molecular markers associated with skin colour, as well as QTLs for soluble solids, dry matter content and pungency, have been reported (Galmarini et al. 2001, McCallum et al. 2007, Shigyo and Kik 2008). However, several economically important traits that are quantitatively and probably polygenically controlled are based on phenotypic selection.

The aim of this study is to determine the variability of a set of agronomically relevant traits in an onion landrace, and the variability within and among $\mathrm{S}_{1}$ lines obtained after a single selfing generation. In addition, heritability was determined using parent-offspring regression, and the correlations were estimated. These results gave indications of diversity within the landrace UR9719 and the fitness of the $\mathrm{S}_{1}$ line method for breeding.

\section{MATERIAL AND METHODS}

\section{Plant material}

Bulbs from the landrace UR9719 were selected for round shape, dark brown colour of the skin and persistence of a high number of skins. Selected bulbs were planted out in 2007 and forced to selfing by covering each plant with individual paper bags at flowering time to obtain $\mathrm{S}_{1}$ lines or full-sib families with one selfing cycle. Harvested seeds were sown in seedbeds in May 2008. Fifty-one $\mathrm{S}_{1}$ lines or full-sib families produced enough seedlings and were included in this study. The original UR9719 population was also sown in a seedbed. Seedlings were transplanted in September.

\section{Experimental design}

An incomplete block design with augmented checks, including the original landrace UR9719, was used. Thirtysix $\mathrm{S}_{1}$ lines were included in three blocks, while $15 \mathrm{~S}_{1}$ lines were included only in two blocks due to limited seed availability. Each block had 64 plots and each plot had eight plants. The distance between plants was $20 \mathrm{~cm}$ and between rows was $75 \mathrm{~cm}$. The borders of the trial were planted with the landrace UR9719. Nitrogen in the form of urea $(120 \mathrm{~kg}$ $\mathrm{ha}^{-1}$ ) was applied seven days after transplanting. Linuron (Lanafil S.A., Uruguay) was applied for weed control fifteen days after transplanting. The trial was irrigated as needed throughout the growing period using drip irrigation.

\section{Measured traits}

A set of qualitative and quantitative traits were measured before harvest, at harvest, and after harvest. Before harvest (75-80 days after transplanting), leaf colour [according to IPGRI (2001)], maximum leaf length (MLL), number of leaves, neck diameter (ND1) and equatorial diameter of the immature bulb (EDIB) were measured once for each individual plant. Bulbing index at this time (BI1) was calculated as the ratio EDIB/ND1. At harvest (94 to 141 days after transplanting), the state of foliage was recorded in two categories (senescent or fold-down), and the number of days until harvest (DUH) was calculated. After curing, bulb weight (BW) was determined, the equatorial diameter of the mature bulb (EDMB) was measured, and the bulbing index of the mature bulb (BI2) was calculated. Bulb shape was classified according to IPGRI (2001), and the number and colour of skins were determined (IPGRI 2001). Soluble solids content (SSC) was measured with a digital Abbe refractometer (Beijing Frbiz Electronic Ltd., China), and dry matter content (DMC) was determined by oven drying the top half of each bulb $\left(48 \mathrm{~h}\right.$ at $\left.105^{\circ} \mathrm{C}\right)$.

\section{Data analysis}

For each quantitative trait, univariate analysis of the landrace and the group of $\mathrm{S}_{1}$ lines was performed in order to have a descriptive analysis, and to quantify the effect of selfing and the response to selection. F-Statistics (i.e. the ratio of MS between UR9719 and $\mathrm{S}_{1}$-lines to MSE) were estimated in order to detect differences between the landrace UR9719 and the $\mathrm{S}_{1}$ lines.

Variances within the landrace UR9719 among S1 lines and within them were calculated in order to estimate variability for quantitative agronomic traits. To estimate variances among and within $\mathrm{S} 1$ lines, the following random effects model was used: $\mathrm{Y}_{\mathrm{ijk}}=\mu+\beta_{\mathrm{i}}+\gamma_{(\mathrm{ji}))}+\mathrm{L}_{\mathrm{k}}+\varepsilon_{\mathrm{ijk}}+\delta_{\mathrm{ijkl}}$, where $Y_{i j k}$ is the response variable (i.e. each one of the quantitative traits studied) of the $l$ th plant from the $k$ th line in the $j$ th incomplete block of the $i$ th complete block; $\mu$ is the overall mean; $\beta_{i}$ is the effect of the $j$ th complete block, $\gamma_{j(i)}$ is the effect of the $j$ th incomplete block-effect nested within the $i$ th complete block, $L_{k}$ is the effect of the $k$ th line, $\varepsilon_{i j k l}$ is the residual error associated with each experimental unit, and $\delta_{i j k l}$ is the sub-sampling effect associated with the $l$ th plant within the experimental unit. To estimate components of variance in the landrace, a very similar model was used in which the line effect is not present. All components of variance were estimated with the PROC MIXED procedure 
and the restricted maximum likelihood method in SAS (Littell et al. 1996). Variability for qualitative traits was calculated using the Likelihood Ratio Chi-square Statistic, and distribution of frequencies forS $\mathrm{S}_{1}$ lineswere compared with the landrace UR9719 and among $\mathrm{S}_{1}$ lines.

Broad sense heritability was calculated using the method of parent-offspring regression. The following linear regression model was applied: $\mathrm{Y}_{\mathrm{i}}=\mathrm{a}+\mathrm{bX}+\mathrm{e}_{\mathrm{i}}$, where $Y_{i}$ is the estimated performance of the offspring descendent of the $i$ parent, $a$ is the mean of the parents, $b$ is the linear regression coefficient, $X_{i}$ is the performance of the $i$ parent, and $e_{j}$ is the experimental error associated with the measurement of $X_{i}$. The equation for the linear regression coefficient is $\mathrm{b}$ $=\sigma_{\mathrm{xy}} / \sigma_{\mathrm{wp}}^{2}$, where $\sigma_{x y}$ is the covariance between the parents $(x)$ and their offspring (y),estimated by the between-line variance, and is the phenotypic variance in the parents (Falconer and Makay 1996).

In order to estimate correlations among quantitative traits, the PROC CORR procedure of SAS statistical package (SAS Institute 1990) was used. An estimate of the association between qualitative and quantitative variables was obtained through an analysis of variance for each quantitative variable against each qualitative variable, one at a time (the amount of association is provided by the F-value).

\section{RESULTS AND DISCUSSION}

\section{Selfing and selection effects}

The mean values of the landrace UR9719 were significantly greater than the mean values of the $51 \mathrm{~S}_{1}$ lines for all quantitative traits, except for dry matter and soluble solidscontents (Table 1). Dry matter $(\mathrm{p}<0.001)$ and soluble solids $(\mathrm{p}<0.05)$ contents were significantly larger for $S_{1}$ lines, while bulb weight, maximum leaf length, equatorial diameter of immature and mature bulb, and bulbing index of the mature bulb were significantly larger for the landrace UR9719 $(p<0.001)$. Mean values of the $S_{1}$ lines and the landrace differed significantly also for neck diameter of the immature bulb, bulbing index for the immature bulb and soluble solids content with $\mathrm{p}<0.05$ (Table 1 ).

Therefore, inbreeding depression occurred after only one cycle of selfing for all traits related to plant vigour. Outcrossing species like onion suffer from inbreeding depression when selfing is artificially applied (Poehlman and Sleper 1995). Inbreeding depression is an undesirable consequence of breeding methods aiming at unravelling and controlling genetic variation from the high variability of random pollinated populations. Nevertheless, normal plant growth is recovered and yield depression is eliminated in further breeding generations by restitution of cross-pollination between selected plants (Poehlman and Sleper 1995).

Onion breeding ends up mostly with $\mathrm{F}_{1}$-hybrid and open-pollinated cultivars (Kik et al. 1998). Hybrid onion prevails in developed countries, whereas open-pollinated cultivars are extensively grown in other regions around the world (van der Meer 1994). Inbreeding is a required step in developing hybrids, and a useful tool in developing openpollinated onion cultivars. Hybrids could be even regarded as an advanced specific form of $\mathrm{S}_{1}$ or full-sib family selection (Shigyo and Kik 2008). However, open-pollinated cultivars are a feasible option wherever hybrid development is not established and locally developed onion cultivars outperform introduced hybrids (Kik et al. 1998, Cramer 2001).

Table 1.Mean values, standard error of the mean (SE), maximum and minimum values for quantitative traits in the onion landrace UR9719 and the group of derived $S_{1}$ lines; F-Statistic as a comparison of mean values between the landrace UR9719 and the group of $\mathrm{S}_{1}$ lines

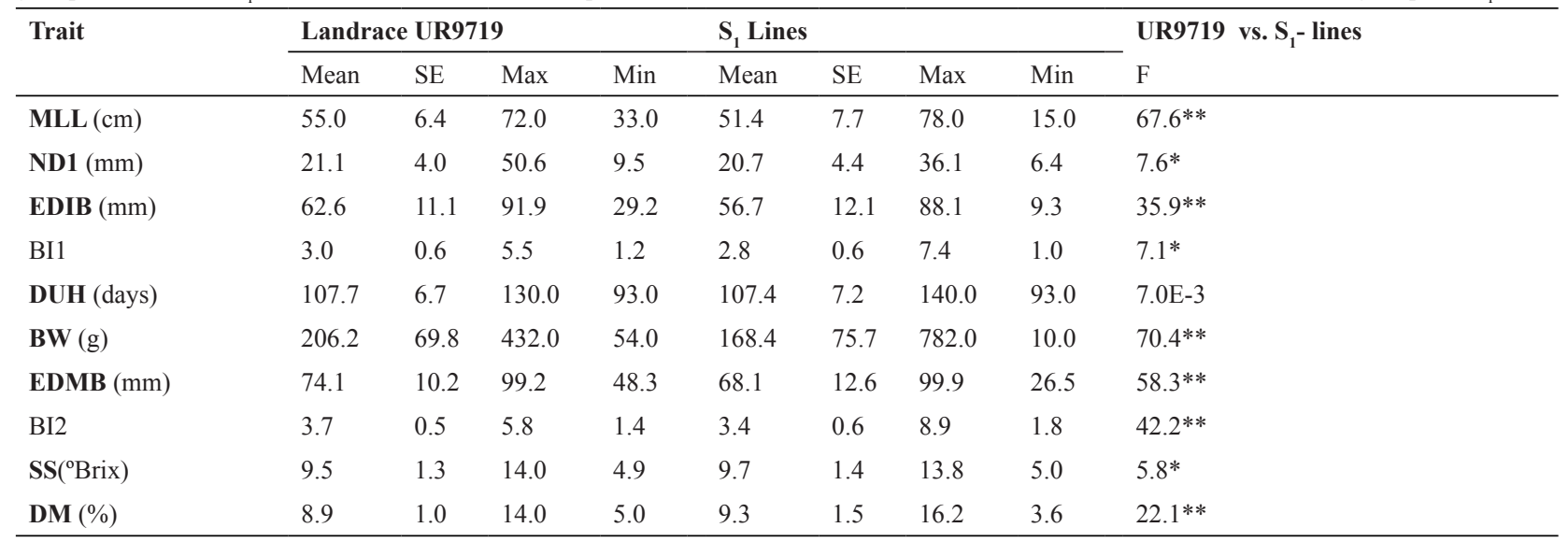

$* \mathrm{p} \leq 0.05 * * \mathrm{p} \leq 0.001, \mathbf{M a x}=$ maximum value observed within the category, $\mathbf{M i n}=$ minimum value observed within the category, $\mathbf{F}=\mathrm{F}-\mathrm{Statistic}, \mathbf{M L L}=\mathbf{M a x i m u m}$ leaf length $(\mathrm{cm}), \mathbf{N D 1}=$ Neck diameter of immature bulb $(\mathrm{mm}), \mathbf{E D I B}=$ Equatorial diameter of immature bulb $(\mathrm{mm}), \mathbf{B I 1}=$ Bulbing index of immature bulb $($ during the plant growth), DUH= Days until harvest (days from transplanting), $\mathbf{B W}=$ Bulb weight ( $\mathrm{g}$ ), EDMB = Equatorial diameter of mature bulb (mm), BI2= Bulbing index of mature bulb, $\mathbf{S S}=$ Soluble solids content (Degrees Brix), $\mathbf{D M}=$ dry matter content (as a proportion of fresh matter weight). 
Another consequence after one cycle of selfing in outcrossing species is the occurrence of transgressive segregation in the offspring (Fehr 1987). In our study, $S_{1}$ lines, as a group, showed a wider range, with larger maximum and smaller minimum values than the landrace UR9719 for maximum leaf length, bulbing index of immature bulbs, bulb weight, equatorial diameter of mature bulbs, and dry matter content (Table 1). For these traits, $S_{1}$ plants with values outside of the range of the landrace UR9719 were recorded, either at the lower or the upper limits.

The occurrence of transgressive segregation is a desirable consequence of the development of $\mathrm{S}_{1}$ lines since it enables the selection of genotypes better than the parents (Poehlman and Sleper 1995). McCallum et al. (2006) found transgressive segregation for fructan and fructose contents in the offspring between contrasting inbred onion lines. Offspring plants outperformed parents for plant vigour in an inter-specific Allium population (Galván et al. 2011). For cultivated plants, Riesberg et al. (1999) reviewed results from several authors and found that transgressive segregation seems to be the rule in populations involving intraspecific inbreeding and crosses.

Qualitative traits were analysed by frequency-distribution comparisons. Leaf colour, number of leaves, state of senescence at harvest, bulb shape, external colour of the bulb and number of skins showed significant differences among UR9719 and $\mathrm{S}_{1}$ lines $(\mathrm{p}<0.05)$. In addition, external colour and number of skins responded to selection (Figure 1). $\mathrm{S}_{1}$ lines showed an increase in the mean number of skins per bulb, with greater frequencies of bulbs with five or more skins, and increased relative frequency of darker colours of skins (Figure 1). Genetic progress in these two economically
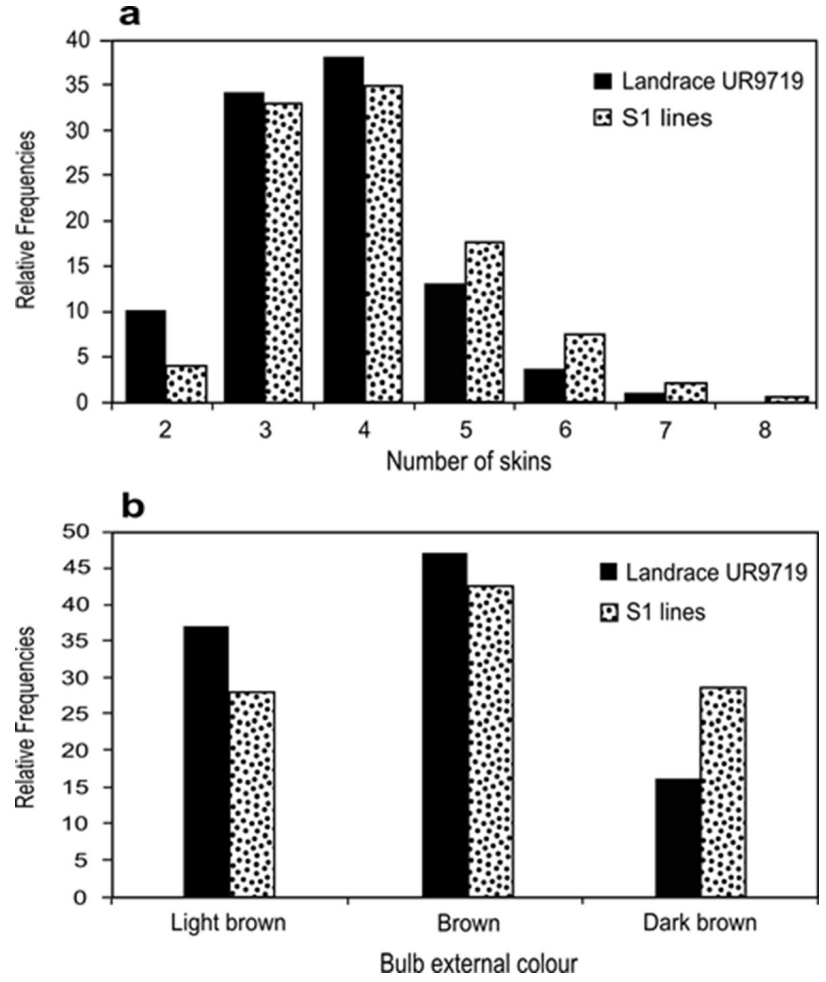

Figure 1.Relative plant frequencies in the onion landrace UR9719 and the derived $\mathrm{S}_{1}$ lines for (a) the number of skins per bulb, and (b) the external colour of the bulb. Distributions significantly differ for both traits (Likelihood Chi-Square ratio, $\mathrm{p}<0.001)$.

important traits (Shigyo and Kik 2008) could be the result of both transgressive segregation (with the appearance of extreme values not recorded for the landrace UR9719) and response to selection. Selection of $\mathrm{S}_{1}$ mother bulbs in the original population may explain the increase in relative

Table 2.Variances for quantitative traits within the onion landrace UR9719, within derived $\mathrm{S}_{1}$ lines and among $\mathrm{S}_{1}$ lines

\begin{tabular}{|c|c|c|c|c|c|c|}
\hline \multirow{2}{*}{ Trait } & \multicolumn{2}{|c|}{ Landrace UR9719a } & \multirow[b]{2}{*}{$\sigma^{2}$} & \multirow{2}{*}{$\begin{array}{l}\text { Within } S_{1} \text { lines }^{\mathrm{a}} \\
\mathrm{SE}\end{array}$} & \multirow[b]{2}{*}{$\sigma^{2}$} & \multirow{2}{*}{$\begin{array}{l}\text { AmongS }_{1} \text { lines }^{\mathrm{a}} \\
\mathrm{SE}\end{array}$} \\
\hline & $\sigma^{2}$ & SE & & & & \\
\hline MLL (cm) & 41.14 & $(2.80)$ & 42.81 & $(2.08)$ & 17.51 & $(4.05)$ \\
\hline BI1 & 0.27 & $(0.02)$ & 0.22 & $(0.01)$ & 0.08 & $(0.02)$ \\
\hline DUH (days) & 44.85 & $(3.04)$ & 41.60 & $(2.03)$ & 10.49 & $(2.81)$ \\
\hline EDMB (mm) & 97.09 & $(7.43)$ & 131.26 & $(6.75$ & 22.87 & $(6.26)$ \\
\hline BI2 & 0.27 & $(0.02)$ & 0.24 & $(0.01)$ & 0.08 & $(0.02)$ \\
\hline SS $\left({ }^{\circ}\right.$ Brix $)$ & 1.66 & $(0.12)$ & 1.16 & $(0.06)$ & 0.60 & $(0.14)$ \\
\hline $\mathrm{DM}$ & $1.36 \mathrm{E}-04$ & $(9.77 \mathrm{E}-06)$ & $1.32 \mathrm{E}-04$ & $(6.85 \mathrm{E}-06)$ & $7.15 \mathrm{E}-05$ & $(1.59 \mathrm{E}-05)$ \\
\hline
\end{tabular}

${ }^{a}$ Variances of the landrace, between and within $\mathrm{S}$, lines significantly different from each other for all traits $(\mathrm{p} \leq 0.001), \mathbf{S E}=\mathrm{Standard}$ error, $\mathbf{M L L}=\mathrm{Maximum}$ leaf length $(\mathrm{cm}), \mathbf{N D 1}=$ Neck diameter of immature bulb $(\mathrm{mm}), \mathbf{E D I B}=$ Equatorial diameter of immature bulb $(\mathrm{mm}), \mathbf{B I 1}=$ Bulbing index during the season, DUH= Days from transplanting until harvest, $\mathbf{B W}=$ Bulb weight $(\mathrm{g}), \mathbf{E D M B}=$ Equatorial diameter of mature bulb $(\mathrm{mm}), \mathbf{B I 2}=\mathrm{Bulbing}$ index after curing, $\mathbf{S S}=\mathrm{Soluble}$ solids content $\left({ }^{\circ} \mathrm{Brix}\right)$, $\mathbf{D M}=$ Dry matter content as a proportion of fresh matter weight. 
frequencies of upper categories among and within $\mathrm{S}_{1}$ lines.

Variability within the landrace UR9719, and within and among $\mathrm{S}_{1}$ lines

All quantitative traits showed significant variance among plants within the landrace UR9719 (REML analysis, Table 2), and significant variance within $S_{1}$ lines $(p<0.001)$. After one cycle of selfing, maximum leaf length, equatorial diameter of immature and mature bulbs and bulb weight increased their variability in comparison with the landrace UR9719. Variance among $\mathrm{S}_{1}$ lines proved to be significant in all the quantitative traits studied $(p<0.001)$, although variability within $\mathrm{S}_{1}$ lines was greater than variability among $\mathrm{S}_{1}$ lines (Table 2).

Significant variance within and among onion populations made the selection of genotypes with high breeding potential possible (Havey 1993). In regard to the significant variance found in the original population, within $\mathrm{S}_{1}$ lines and among $\mathrm{S}_{1}$ lines, the landrace UR9719 was highly heterogeneous, allowing the selection of plants of interest for breeding. Furthermore, for some traits (bulb weight, bulb diameter) there was even more heterogeneity within $\mathrm{S}_{1}$ lines than in UR9719, which allows a more efficient selection of genotypes within $\mathrm{S}_{1}$ lines.

According to the Likelihood Chi-Square ratio, leaf colour, number of leaves, state of senescence at harvest, bulb shape, external colour of the bulb, and number of skins per bulb showed differences in distribution of frequencies among $\mathrm{S}_{1}$ linesand the landrace UR9719 $(\mathrm{p}<0.001)$. There was significant variability among $\mathrm{S}_{1}$ lines for all the qualitative traits studied. Therefore, selection between lines may be efficient.

A breeding programme based on UR9719 could involve selection within and among $\mathrm{S}_{1}$ lines and broaden the possibilities of achieving greater genetic progress than that obtained through mass selection. In agreement with the methods already applied for the development of openpollinated cultivars currently available in Uruguay (Vilaró et al. 2005), $S_{1}$ lines would be a useful selection method for this plant material.

\section{Estimates of heritability and correlations}

Parent-offspring regression revealed that dry matter content had the highest value of broad sense heritability $(52.6 \%)$, followed by maximum leaf length $(42.6 \%)$ and soluble solids content (36.1\%) (Table S1). Heritability of a trait is determined by the population studied, the environment, and the method used (Fehr 1987), so differences between reports are commonly found. Dry matter and soluble solids content of the bulb are two interesting traits in onion breeding because they are directly related to storage ability and commercial quality (Patil and Kale 1985, McCallum et al. 2006). In this study, broad sense heritability of dry matter and soluble solids content was greater than values reported in Allium cepa var. aggregatum (Maia et al. 2008), though smaller than narrow sense heritability values found by Galmarini et al. (2001). Nevertheless, the heritability observed in our material would allow significant genetic progress for these traits, and indirectly allow progress for post-harvest storage ability (Patil and Kale 1985). Maximum leaf length was the second trait with high heritability, as also found by Maia et al. (2008), followed by soluble solids content, a trait with high heritability reported for several onion populations (Buso and Costa 1979, Wall and Corgan 1999, Galmarini et al. 2001).

The lowest heritability values were observed for equatorial diameter of mature (23.6\%) and immature (18.3\%) bulbs, days until harvest (23.4\%), and bulb weight (16.2\%) (Table S1). Low broad heritability for bulb diameter and weight are usually found since these traits are highly influenced by the environment and crop management. For instance, McCollum (1966) reported heritability values between 0 and 11\%, whereas Buso and Costa (1979) reported 39\%. Working with wider collections of several onion populations and cultivars, other studies reported higher broad heritability (66 to $90 \%$ ) for bulb weight or bulb diameter (Cardoso and Costa 2003, Ram et al. 2011). Regarding our onion population, UR9719, yield improvement should be addressed by another method, such as stratified mass selection, to ensure genetic progress.

Association analysis among quantitative and qualitative variables (data not shown) indicated that candidates for indirect selection could be the number of leaves for bulb weight $(\mathrm{F}=26.9)$; and skin colour for dry matter content $(\mathrm{F}=28.9)$ and for soluble solids content $(\mathrm{F}=12.9)(\mathrm{P}<0.0001$ in all cases). Darker skin colours were associated with higher contents of dry matter and soluble solids.

The bulbing index during the season and the bulbing index after harvest presented the highest correlation among the traits studied (Table S2). Dry matter and soluble solids contents were the second pair of significantly correlated traits $(0.83)$, in agreement with previous reports (Mann and Hoyle 1945, Nieuwhof et al. 1973, Sinclair et al. 1995, Galmarini et al. 2001). This positive correlation makes the use of indirect selection by soluble solids content possible; soluble solids content is easier and cheaper to measure than dry matter content for large scale plant material. Conversely, negative correlation $(-0.31)$ was found between dry matter content and the equatorial diameter of mature bulbs $(\mathrm{p}<0.05)$. As storage ability is directly related to dry matter and soluble solids content (Patil and Kale 1985), larger bulbs would have less storage potential. 
Positive and high correlations were also found between traits related to plant vigour (Table S2): bulb weight, maximum leaf length, equatorial diameter of immature and mature bulbs, and neck diameter of immature bulbs $(\mathrm{p}<0.001)$. Bulbing index during the season $(-0.56)$ and after harvest $(-0.36)$ were negatively correlated with the number of days until harvest. This indicates that the earlier the bulbing process is, the shorter the growing cycle until harvest will be.

The bulbing index after harvest was also negatively correlated with the soluble solids $(-0.28)$ and dry matter content $(-0.32)$. The bulbing index, calculated as the ratio between equatorial bulb diameter and neck diameter, was regarded as a good indirect selection index for post-harvest storage ability because it gives an indication of neck thickness (Patil and Kale 1985) and of the balance between foliage and the bulbing growth phases. The selection of bulbs with a larger bulbing index permits a reduction in neck diseases, delayed sprouting after storage and, consequently, increased postharvest storage ability (Sandhu et al. 1975, Singh and Joshi 1978). For our landrace population and derived inbreeds, however, the bulbing index after harvest was negatively correlated with soluble solids and dry matter contents; therefore, indirect selection based on the bulbing index should be carried out with caution.

\section{ACKNOWLEDGEMENTS}

We express our thanks for financial support from project FPTA-INIA 250 (Instituto Nacional de Investigación Agropecuaria), Uruguay.

\section{Variabilidade, herdabilidade e correlações de caracteres agronômicos em uma variedade crioula de cebola e linhas $S_{1}$ derivadas}

Resumo - Foram avaliados variabilidade, herdabilidade e correlações de caracteres agronômicos em uma variedade crioula de cebola (Allium cepa $L$.) e linhas $S_{1}$ derivadas após uma geração de autofecundação. Para produzir linhas $S_{1}$ foram selecionados bulbos por forma, cor e número de cascas. Cinquenta e uma linhas $S_{1}$ e a população original foram avaliados em blocos incompletos casualizados. Houve variabilidade para caracteres quantitativos e qualitativos. As linhas $S_{1}$ diferiram significativamente entre si, apresentando segregação transgressiva para número e comprimento de folhas, índice de bulbificação, peso e diâmetro de bulbo e conteúdo de matéria seca. As variâncias dentro das linhas $S_{l}$ foram maiores do que entre elas, para todos os caracteres. Cor de bulbo e número de cascas responderam à seleção. Matéria seca e sólidos solúveis foram altamente correlacionados, com herdabilidades de 52,6\% e 36,1\%, respectivamente. As linhas $S_{1}$ permitiram expressão da variação genética e identificação dos melhores genótipos para caracteres agronômicos de interesse.

Palavras-chave: Autofecundação, segregação transgressiva, depressão por endogamia, matéria seca, sólidos solúveis.

\section{REFERENCES}

Buso JA and Costa CP (1979) Heritability and correlation of onion bulb traits (Allium cepa L.). Brazilian Journal of Genetics2: 49-55.

Cardoso AII and Costa CP (2003) Seleção para maturidade de bulbos em cebola. Scientia Agricola 60: 59-63.

Cramer CS (2001) Comparison of open-pollinated and hybrid onion varieties for New Mexico. Hort Technology 11: 119-123

DIEA (2010) Encuestas hortícolas 2009, zona sur y litoral norte. Ministerio de Ganadería, Agricultura y Pesca, DIEA. Montevideo, $30 \mathrm{p}$.

Falconer DS and Mackay TFC (1996) Introduction to quantitative genetics. Pearson Education, Harlow, 464p.

Fehr RW (1987) Principles of cultivar development.Vol1,Macmillan Publishing Company, New York, 536p.

Galmarini CR, Goldman IL and Havey MJ (2001) Genetic analyses of correlated solids, flavor, and health-enhancing traits in onion (Allium cepa L.).Molecular Genetics and Genomics 256: 543-551.

Galván GA, Kuyper TW, Burger K, Keizer LCP, Hoekstra RF, Kik C and Scholten OE (2011) Genetic analysis of the interaction between Allium species and arbuscular mycorrhizal fungi.Theoretical and Applied Genetics122: 947-960.

Galván G, González H and Vilaró F (2005) Estado actual de la investigación en poblaciones locales de hortalizas en Uruguay y su utilización en el mejoramiento. Agrociencia 9: 115-122.

González H, Zaccari F and Suarez C (2000) Conservación de bulbos de poblaciones locales de cebolla. En: Presentación de resultados experimentales de ajo y cebolla. INIA Serie actividades de difusión 223: $41-46$

Hardon JJ and De Boef W (1993) Linking farmers and breeders in local crop development. In De Boef W, Amanor K, Wellard K and Bebbington A (eds.) Cultivating knowledge: genetic diversity, farmer experimentation and crop research. Intermediate technologies publications, London, p. 64-71.

Havey MJ (1993) Onion breeding.InKalloo G and Berg B (eds.) Genetic improvement of vegetable crops. Pergamon Press, Oxford, p. 35-49.

IPGRI (2001) Descriptors for Allium (Allium spp.).International Plant Genetic Resources Institute, Rome, $41 \mathrm{p}$.

Kik C, Wietsma WA and Verbeek WHJ (1998) Onion.InBanga SS and Banga SK (eds.) Hybrid cultivar development: concepts and methodologies. Narosa Publ. House, New Delhi, p. 476-485. 
Littell RC, Milliken GA, Stroup WW and Wolfinger RD (1996) SAS system for mixed models. SAS Institute, Cary, 633p.

Maia MCC, Pedrosa JF, Rocha MM, Paiva WO and Sousa GH (2008) Estimativas de parámetros genéticos e fenotípicos em cebola múltipla. Caatinga 21: 101-106

Mann LK and Hoyle BJ (1945) Use of the refractometer for selection of onion bulbs high in dry matter for breeding. Proceedings of the American Society for Horticultural Science 46: 285-292.

McCallum J, Clarke A, Pither-Joyce M, Shaw M, Butler R, Brash D, Scheffer J, Sims J, van Heusden S, Shigyo M and Havey MJ (2006) Genetic mapping of a major gene affecting onion bulb fructan content. Theoretical and Applied Genetics 112: 958-967.

McCallum J, Pither-Joyce M, Shaw M, Kenel F, Davis S, Butler R, Scheffer J, Jakse J and Havey MJ (2007) Genetic mapping of sulphur assimilation genes reveals a QTL for onion bulb pungency. Theoretical and Applied Genetics 114: 815-822.

McCollum GD (1966) Heritability and genetic correlation of some onion bulb traits: estimates from S1 offspring on parent regression. Journal of Heredity 57: 105-110.

Nieuwhof M, De Bruyn JW and Garretsen F (1973) Methods to determine solidity and dry matter content of onions (Allium cepa L.). Euphytica 22: 39-47.

Patil RS and Kale PN (1985) Correlation studies on bulb characteristics and storage losses in onion. Journal of Maharashtra Agricultural Universities 10: 38-39.

Poehlman JM and Sleper DA (1995) Breeding field crops. lowa State University Press, Ames, 494p.

Ram RB, Bharti N, Meena M.L, Lata R and Babu M (2011) Genetic variability and correlation studies in onion (Allium cepa L.). Vegetos 24: 152-156.

Riesberg LH, Archer MA and Wayne RK (1999) Transgressive segregation, adaptation and speciation. Heredity 83: 363-372

SAS Institute (1990) User's guide: basics and statistics. SAS Institute, Cary, 795p.

Sandhu JS, Thakur JC and Nandpuri KS (1975) Studies on the storage quality of red and white onion varieties. Journal of Research Punjab Agricultural University 13: 279-282.

Shigyo M and Kik C (2008) Onion. In Prohens J and Nuez F (eds.) Vegetables: handbook of plant breeding. Vol. 2, Springer Verlag, Berlin, p.121-162.

Sinclair PJ, Blakeney AB and Barlow EWR (1995) Relationship between dry matter content, soluble solids concentrations and non-structural carbohydrates composition in the onion (Allium cepa L.). Journal of the Science of Food and Agriculture 69: 203-209.

Singh DP and Joshi MC (1978) Correlation studies of rotting and sprouting losses of onion with other traits during storage. Vegetable Science 5: $1-3$.

Van der Meer QP (1994) Onion hybrids: evaluation, prospects, limitations and methods. Acta Horticulturae 358: 243-248.

Vilaró F, Vicente E, Pereyra G and Rodríguez G (2005) Cultivares y mejoramiento genético en cebolla. InArboleya J (ed.) Tecnología para la producción de cebolla.INIA, Uruguay. p. 31-42 (Boletín de Divulgación 88).

Wall AD and Corgan JN (1999) Heritability estimates and progeny testing of phenotypic selections for soluble solids content in dehydrator onion. Euphytica 106: 7-13. 